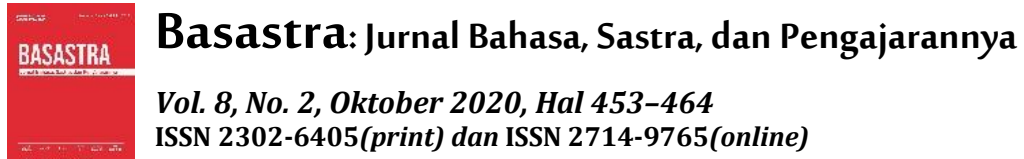

\title{
TINDAK TUTUR RIDWAN REMIN PADA STAND UP COMEDY INDONESIA SEASON 7 KOMPAS TV EDISI JUNI 2017
}

\author{
Tilsep Jasnain \\ Universitas PGRI Palembang \\ Email: jasnaindolken43@gmail.com
}

\begin{abstract}
Abstrak: Masalah dari penelitian ini adalah apa sajakah tindak tutur Ridwan Remin pada Stand Up Comedy Indonesia season 7 Kompas TV edisi Juni 2017. Tujuan dari penelitian ini adalah untuk mengetahui dan mendeskripsikan tindak tutur Ridwan Remin dalam penampilannya dalam Stand Up Comedy yang mengkhususkan pada tindak tutur lokusi, ilokusi dan perlokusi. metode yang digunakan dalam penelitian ini adalah metode deskriptif kualitatif. Sumber data dan objek penelitian adalah video penampilan Stand Up Comedy Ridwan Remin pada acara Stand Up Comedy Indonesia season 7 kompas TV edisi Juni 2017 sebanyak 5 video. Tekhnik analisis data yaitu menggunakan tekhnik dokumentasi. Hasil analisis yang diperoleh yaitu berupa 20 kalimat tuturan tindak lokusi, 10 kalimat tuturan tindak ilokusi, dan 3 kalimat tuturan tindak perlokusi. dalam penuturan tentu diperlukan tindak tutur agar maksud dalam penuturan dapat tersampaikan kepada mitra tutur sehingga dapat menimbulkan reaksi atau hubungan timbal balik bagi penutur.
\end{abstract}

Kata Kunci: ridwan remin, stand up comedy, tindak tutur.

\section{RIDWAN REMIN'S TUTORIAL AT THE STAND UP COMEDY INDONESIA SEASON 7 KOMPAS TV, JUNE 2017 EDITION}

\begin{abstract}
The problem of this research is what are Ridwan Remin's speech acts in the June 2017 edition of Stand Up Comedy Indonesia, Kompas TV. The purpose of this study is to find out and describe Ridwan Remin's speech acts in his appearance in Stand Up Comedy which specializes in locus speech acts, illocution and perlocution. The method used in this research is descriptive qualitative method. The data source and the object of the research were the videos of Ridwan Remin's Stand Up Comedy performance at the Stand Up Comedy Indonesia season 7, Kompas TV June 2017 edition, consisting of 5 videos. Data analysis techniques are using documentation techniques. The analysis results obtained are in the form of 20 sentences of speech action locus, 10 sentences of speech acts of illocution, and 3 sentences of speech acts of perlocution. In speech, of course, speech acts are needed so that the meaning in the speech can be conveyed to the speech partner so that it can cause a reaction or reciprocal relationship for the speaker.
\end{abstract}

Keywords: Ridwan Remin, Speech Action, Stand Up Comedy

\section{PENDAHULUAN}

Keterampilan berbahasa dalam kurikulum di sekolah mencakup empat segi, yaitu menyimak, berbicara, membaca, dan menulis. Keempat keterampilan tersebut pada dasarnya merupakan satu kesatuan yang disebut catur tunggal. Pada hakikatnya keempat keterampilan tersebut saling

BASASTRA Jurnal Bahasa, Sastra, dan Pengajarannya

Volume 8 Nomor 2, Oktober 2020, P-ISSN 2302-6405, E-ISSN 2714-9765 
memiliki keterkaitan satu sama lain dalam proses berpikir dan berbahasa. Hal ini didukung oleh (Tarigan, Menyimak, 2008) bahwa setiap keterampilan itu erat pula hubungannya dengan proses-proses berpikir yang mendasari bahasa. Bahasa seseorang mencerminkan pikirannya. Semakin terampil seseorang berbahasa, semakin cerah dan jelas pula jalan pikirannya. Selaras dengan itu dalam jurnalnya (Yanti, 2018) menyatakan Keterampilan berbahasa Indonesia mencakup keterampilan menyimak, keterampilan berbicara, keterampilan menulis, dan keterampilan membaca. Keempat keterampilan tersebut saling terkait antara yang satu dengan yang lain.

Stand up comedy merupakan salah satu jenis dari public speaking yang sama-sama bertujuan untuk menyampaikan sebuah pendapat, ide dan pemikiran namun dikemas dengan unsur komedi. Hal ini sesuai dengan pendapat (Papana, 2012) yang menyatakan Bit ini terdiri dari sebuah set-up dan punchline yang tercipta dari hasil pemikiran, gagasan dan keresahan. stand up comedy adalah sebuah bentuk pertunjukan seni komedi. Biasanya, seorang komedian tampil didepan para penonton dan berbicara langsung kepada mereka. Para penampil ini biasanya disebut sebagai seorang komika. seorang komika membawakan materi berupa cerita singkat yang lucu, atau disebut dengan bit untuk disampaikan kepada penonton. Pendapat ini juga berkaitan dengan jurnal (Wahyuningsih, Hikmah \& Zainal Rafli, 2017) yang mengemukakan bahwa stand up comedy merupakan sebuah hiburan dimana hanya seseorang berdiri atau yang biasa disebut comica didepan dan berbicara kepada penonton dan menghibur dengan tema-tema yang mengandung sentilan terhadap lingkungan-lingkungan atau fenomena-febomena yang ada di sekitar kita.

Di Indonesia perkembangan stand-up comedy berkembang pesat sejak munculnya acara pencarian bakat stand-up comedy Indonesia yang ditayangkan oleh salah satu stasiun televisi swasta di Indonesia. Sejak kemunculan acara tersebut barulah bermunculan komunitas-komunitas stand-up comedy diseluruh Indonesia. Mulai dari Aceh sampai Manado, Samarinda, Bali, Cianjur, dan Depok, baik di kota, pelosok, kampus, maupun sekolah. Begitu antusiasnya kaum muda dan masyarakat Indonesia untuk menikmati gelak tawa suguhan hiburan komedi. maka timbulah minat yang luas dari kalangan pemuda untuk bercita-cita menjadi seorang komika dan menjadikan stand up comedy sebagai profesi. Acara pencarian bakat stand up comedy Indonesia di Kompas TV telah mencapai pada season kedelapan. Baik dari season pertama sampai terakhir saat ini banyak bermunculah komika-komika berkelas dalam pembawaannya menyampaikan

BASASTRA Jurnal Bahasa, Sastra, dan Pengajarannya

Volume 8 Nomor 2, Oktober 2020, P-ISSN 2302-6405, E-ISSN 2714-9765 
sebuah bit comedy atau cerita lucu yang dibawakan. salah satu yang terbaik menurut penulis ialah Ridwan Remin yang merupakan juara pertama pada season 7 acara tersebut. Ridwan remin merupakan komika berkelas dalam penulisan dan pembawaan nya bahkan seorang juri dan legenda komedi Indonesia Indro Warkop mengatakan bahawa Ridwan Remin adalah seorang stand up comedian cerdas yang ada di Indonesia dengan penulisan yang rapi serta pembawaannya yang dapat mentransformasikan sesuatu dalam pemikirannya kepada penonton begitu baik. tidak hanya Indro Warkop, Pandji Pragiwaksono yang juga merupakan juri dalam acara tersebut berpendapat bahwa Ridwan Remin adalah komika yang layak dan berhak di tonton oleh seluruh rakyat Indonesia dengan kematangan materi dan penulisannya. kemudian dalam keterampilan berbicara di atas panggung untuk menghibur penonton yang dilakukan oleh Ridwan Remin terdapat ujuran atau tindak tutur yang juga begitu penting.

Fokus penelitian yang dilakukan oleh penulis ialah penampilan Ridwan Remin pada Stand Up Comedy Indonesia Season 7 Kompas TV edisi Juni 2017. Subfokus dalam penelitian ini ialah pemakaian tindak tutur lokusi, ilokusi dan perlokusi Ridwan Remin pada Stand Up Comedy Indonesia Season 7 Kompas TV edisi Juni 2017.
Rumusan masalah dalam penelitian ini adalah menemukan dan menjelaskan hal-hal apa sajakah tindak tutur yang digunakan oleh Ridwan Remin pada Stand $U p$ Comedy Indonesia Season 7 Kompas TV edisi Juni 2017.

Tujuan dari penelitian ini ialah mendeskripsikan penggunaan tindak tutur Ridwan Remin pada Stand Up Comedy Indonesia Season 7 Kompas TV edisi Juni 2017.

\section{METODE PENELITIAN}

Objek penelitian ialah seorang juara kompetisi Stand Up Comedy Indonesia Season 7 Kompas TV yaitu Ridwan Remin. Informan penelitian adalah beberapa buku mengenai pragmatik dan stand up comedy serta video-video stand up comedy Ridwan Remin.

Metode penelitian yang digunakan penulis ialah metode penelitian kualitatif dengan pendekatan deskriptif. Metode penelitian kualitatif dilakukan dalam situasi yang wajar dan data yang dikumpulkan umumnya bersifat kualitatif. Metode ini berusaha memahami dan menafsirkan makna suatu peristiwa interaksi tingkah laku manusia dalam situasi tertentu menurut perpektif peneliti sendiri.

$$
\text { Penelitian deskriptif }
$$

bermaksud membuat pemeriaan (penyaderaan) secara sistematis, faktual, dan akurat mengenai faktafakta dan sifat-sifat populasi tertentu (Usman \& Homo Setiady Akbar, 2001). Sedangkan (Sukardi, 2010) menjelaskan bahwa Pendekatan deskriptif adalah penelitian yang 
berusaha menggambarkan dan menginterpretasi objek sesuai dengan apa adanya. Jadi penelitian yang dilakukan oleh penulis adalah penelitian yang bermaksud untuk mengetahui jenis tindak tutur Ridwan Remin pada Stand Up comedy Indonesia Season 7 Kompas TV edisi Juni 2017.

Dalam hal ini metode diperlukan guna melengkapi hal-hal yang dirasa belum cukup dalam datadata yang telah diperoleh melalui pengumpulan lewat dokumen/catatan yang ada dan dianggap relevan dengan masalah yang diteliti. Selain itu Peneliti juga melakukan pengumpulan data yang dilakukan dengan cara mempelajari dokumen-dokumen tertulis, peraturan perundangundangan, dan sumber tertulis lainnya yang berhubungan dengan masalah yang akan diteliti. Jadi peneliti memperoleh data melalui file-file video yang bersumber dari youtube dan televisi. Teknik analisis data yang digunakan oleh peneliti adalah teknik analisis data deskriptif kualitatif. Analisis tersebut memberikan penjelasan dan penguraian yang mendalam mengenai objek yang diteliti. Data-data yang telah diperoleh oleh peniliti akan dianalisis secara deskriptif kualitatif untuk memberikan uraian kepada pembaca tentang apa saja jenis tindak tutur Ridwan Remin pada Stand Up Comedy Indonesia Season 7 Kompas TV edisi Juni 2017. Jenis data yang diperlukan dalam penelitian ini berupa tuturan atau pernyataan comic dalam membawakan stand up comedy. Data dikumpulkan melalui teknik dokumentasi. Teknik dokumentasi dilakukan dengan metode unggah, simak, dan catat. Dalam proses pengumpulan data, peneliti mengumpulkan sebanyak lima video stand up comedy Ridwan Remin yang diunggah dari Youtube nya Kompas TV sebagai sumber data. Data yang diperoleh melalui metode simak kemudian diabadikan dengan cara mencatatnya pada lembar analisis. Penggunaan cara ini cukup bermanfaat, karena mengingat penelitian ini memerlukan beberapa kali proses pengecekan agar peneliti dapat mengidentifikasi kemunculan tindak tutur pada pernyataan comic.

$$
\text { Adapun langkah-langkah }
$$

dalam melakukan analisis sebagai berikut :

(1) Menyimak dan Memahami isi dari penampilan video stand up comedy Ridwan Remin.

(2) Membuat Uraian dari Seluruh tuturan yang dilakukan oleh Ridwan Remin pada penampilannya disetiap video Stand Up Comedy Indonesia Season 7 Kompas TV edisi Juni 2017dari lisan kedalam tulisan.

(3) Mengklasifikasikan isi tuturan pada setiap bit yang dibawakan.

(4) Menganalisis jenis tindak tutur yang digunakan dari tuturan Ridwan Remin dalam penampilan pada Stand Up Comedy Indonesia Seadon 7 Kompas TV edisi Juni 2017.

(5) Membahas hasil analisis data tentang tindak tutur Ridwan Remin pada Stand Up Comedy Indonesia Season 7 Kompas TV edisi Juni 2017.

(6) Menyimpulkan Hasil pembahasan tentang tindak tutur Ridwan Remin pada Stand Up comedy Indonesia Season 7 Kompas TV edisi Juni 2017. 


\section{HASIL DAN PEMBAHASAN}

Penelitian ini membahas tentang analisis tindak tutur Ridwan Remin pada Stand Up Comedy Indonesia Season 7 Kompas TV edisi Juni 2017 dan data penelitian adalah tuturan dari Ridwan Remin dalam penampilannya Pada Stand Up Comedy Indonesia season 7 edisi Juni 2017.

Stand Up Comedy Indonesia (Suci) merupakan salah satu acara ajang pencarian bakat untuk para komika yang disiarkan oleh stasiun Televisi Kompas TV. Stand Up Comedy Indonesia (Suci) pertama kali ditayangkan pada tahun 2011 dan telah mengalami pergantian musim pada setiap tahunnya hingga pada saat ini sudah mencapai pada musim kedelapan. Dalam pencarian bakat untuk berstand up comedy acara tersebut menghadirkan beberapa juri yang sangat kompeten dalam melakukan penilaian baik dari segi materi yang dibawakan maupun pada hal tekhnik dari comedian. Kehadiran ajang bakat stand up comedian ini selalu menarik perhatian kalangan masyarakat dan penikmat acara hiburan karena selain menghibur biasanya para comedian sering menyelipkan dan memberikan pesan pesan yang tersirat pada materi yang mereka sampaikan kepenonton.

Acara Stand Up Comedy Indonesia ini telah banyak melahirkan komika- komika yang terkenal seperti Dodit Mulyanto, Kemal Fahlevi, Abdur Arsyad dan lain-lain sebagaianya dari awal musim kemunculan sampai pada saat ini. Komika-komika yang telah diterbitkan oleh ajang pencarian bakat ini memiliki ragam jenis dan tekhnik masing-masing pada gayanya saat menyampaikan keresahan melalui sebuah set comedy. ada yang membawakan cerita mengenai kondisi lingkungan daerah setempatnya ada pula yang mencertikan kritikan pada beberapa peraturan pemerintah serta ada pula yang menceritakan kisahkisah dalam hidupnya sendiri. Ridwan Remin adalah salah satu komika jebolan dari acara tersebut yang merupakan juara pertama pada musim ke-tujuh yang sering menyelipkan nilai-nilai sentilan dalam materi yang dibawakannya baik dari segi nilai kehidupan masyarakat maupun kehidupan pribadinya sendiri.

Tentu saat bercerita dan menyampaikan materinya pada pendengar Ridwan Remin sering mengunakan bahasa kiasan untuk mengungkapan apa yang diinginkan dan disiratkan. Hal ini sangat diPengaruhi oleh bagaimana caranya dalam bertutur ketika penampilannya pada acara tersebut sehingga maksud dan pesan yang ingin disampaikan dapat dipahami oleh penonton maupun penikmat. Maka dari pada itu penulis tertarik untuk menganalisis Tindak Tutur Ridwan Remin pada Stand $U p$ Comedy Indonesia Season 7 Kompas TV edisi Juni 2017.

\section{Hasil Analisis Data}

Tindak tutur lokusi adalah tindakan yang menyatakan sesuatu dalam arti berkata atau tindak tutur dalam bentuk kalimat yang bermakna dan dapat dipahami (chaer \& agustina, 2004). merunjuk pada pengertian tersebut teradapat beberapa tindak tutur lokusi oleh Ridwan Remin pada penampilannya dalam acara stand up comedy Indonesia season 7 Kompas 
TV edisi Juni 2017. berikut ini hasil analisis mengenai tindak tutur lokusi oleh Ridwan Remin Pada Stand Up Comedy Indonesia season 7 Kompas TV edisi juni 2017:

Tuturan (1) Video (1): "sebagai anak kosan gue tuh cuman bisa nikmati kuliner pas awal bulan doang, pas duit masih banyak." (Ridwan Remin) pada Tutuan (1) Video (1) diatas merupakan tindak tutur lokusi karena berisi mengenai pernyataan dan informasi dari kepribadian Ridwan Remin bahwasanya Ia selaku seorang anak kosan hanya bisa menikmati kuliner pas awal bulan tanpa ada harapan untuk mitra tutur memberi belas kasihan pada dirinya.

Tuturan(2) Video(1). "Temen-temen gue juga gitu kalo awal bulan gaya-gayaan datang kewarteg pada petantang-petenteng pada jumawah." (Ridwan Remin)

Pada Tuturan (2) Video (1) merupakan tindak tutur lokusi karena pada tuturan tersebut Ridwan Remin memberikan infomasi tentang temantemannya yang ketika diawal bulan jika pegi atau singgah di warteg selalu suka bergaya dan jumawah seakanakan mereka sedang memiliki keadaan dana yang lebih baik. dikatakan tindak tutur lokusi karena tuturan itu tidak terikat pada kegiatan secara langsung hanya berisi informasi dari kebiasaan teman-temannya.

Tuturan (3) Video (1): "gue juga sama awal bulan makanan itu masih mewah-mewah begitu akhir bulan renyahrenyah" (Ridwan Remin)

Tuturan (3) Video berisi tentang informasi bahwasanya kebiasaan Ridwan Remin selaku anak kosan apabila diawal bulan terdapat makanan masih mewah-mewah dan berbeda ketika akhir bulan yang hanya renyah-renyah. dari Tuturan (3) Video (1) tersebut merupakan pernyataan dari Ridwan Remin tentang kebiasaan anak kosan diawal bulan.

Tuturan (4) Video (1) : "Makanan favorit gue itu peyek" (Ridwan Remin).

Tuturan (4) Video (1) termasuk kedalam tindak tutur lokusi karena tuturan tersebut merupakan pernyataan dari Ridwan Remin mengenai makanan favorit yang disukainya berupa peyek.

Tuturan (5) Video (1) : “Tapi seperti yang kalian lihat badan gue itu kurus gak ada yang percaya gue itu suka makan." (Ridwan Remin).

pada tuturan tersebut dapat dikatakan sebagai tindak tutur lokusi karena berisi informasi tentang seorang Ridwan Remin bahwasanya Ia memiliki badan yang kurus dan tidak ada orang yang percaya jika dia termasuk orang yang suka makan.

Tuturan (6) Video (1): “dari kecil gue itu gak terlalu doyan makan mangkanya nyokap gue itu sering nakut-nakutin gue pakek mitos Ridwan kalo makan habisi kalo ngak nanti nasinya nangis kalian" (Ridwan Remin)

Pada tuturan (6) Video(1) merupakan tindak tutur lokusi karena berisi informasi mengenai kebiasaan Ridwan Remin yang tidak terlalu doyan makan dan sering ditakut-takuti

merupakan tindak tutur lokusi karena

BASASTRA Jurnal Bahasa, Sastra, dan Pengajarannya

Volume 8 Nomor 2, Oktober 2020, P-ISSN 2302-6405, E-ISSN 2714-9765 
oleh ibunya dengan mitos jika makan nasi tidak habis nanti nasinya menangis.

Tindak tutur ilokusi adalah tindakan apa yang ingin dicapai oleh penuturnya pada waktu menuturkan sesuatu dan dapat merupakan tindakan menyatakan berjanji, meminta maaf, mengancam, meramalkan, memerintah, meminta dan lain sebagainya (Nadar, 2009). Dengan demikian dapat diartikan bahwa tindakan ilokusi tidak hanya bermakna untuk menginformasikan sesuatu tetapi juga mengacu untuk melakukan sesuatu sejauh situasi tuturnya dipertimbangkan secara seksama. berikut ini analisis mengenai tindak tutur ilokusi Ridwan Remin pada Stand Up Comedy Indonesia Season 7 Kompas TV Edisi Juni 2017. analisis dilakukan sesuai dengan indikator pada bab sebelumnya.

Tuturan (1) Video (1) : "Begitu akhir bulan duit udah habis mau makan pilih-pilih temen yang masak mana nih samperin ah" (Ridwan Remin)

Tuturan pada tuturan (1)

Video (1) merupakan tindak tutur ilokusi karena pada tuturan tersebut penutur mengajak untuk mitra tutur menghampiri teman yang masak ketika akhir bulan saat kondisi keuangan mulai habis sehingga dapat untuk menumpang makan di tempat teman agar tak mengeluarkan biaya lebih. dikatakan tindak tutur ilokusi karena bermaksud untuk mengajak.

Tuturan (2) Video (1): "mangkanya gue seterkenal apapun gak akan bakalan ada produk makanan yang mau untuk mengndorse gua gak akan karena percuma gak bakalan laku juga ngarepin orang yang beli makanan karena di iklanin sama gua itu sama aja kayk lu ngarepin orang beli produk shampo yang diiklani pakde indro gak bakal laku kecuali shamponya shampo motor, kalau itu mungkin laku pakde motornya." (Ridwan Remin)

Pada tuturan (2) video (1) tuturan tersebut berisi mengenai keluhan seorang Ridwan Remin yang memiliki tubuh yang kurus sehingga tidak akan pernah ada iklan makanan yang datang kepadanya karenan hanya akan menjadi sia-sia sama halnya dengan adanya iklan shampoo yang di iklani oleh pakde indro yang kebetulan tidak memiliki rambut jadi semua akan sia-sia. Tuturan (2) Video (1) dapat dikatakan tindak tutur ilokusi karena memiliki maksud untuk menyampaikan keluhannya.

Tuturan (3) Video (1): "Gue sih jujur aja gak percaya sama mitos itu, karena menurut gue mitos itu tuh aneh dari semua makanan yang ada didunia ketika kita makan gak habis kenapa cuman nasi yang nangis, emang dia serapuh itu Gue sih jujur aja gak percaya sama mitos itu karena menurut gue mitos itu tuh aneh dari semua makanan yang ada didunia ketika kita makan gak habis kenapa cuman nasi yang nangis, emang dia serapuh itu." (Ridwan Remin)

Tuturan pada Tutuan (3) Video (1) membahas mengenai ketidakpercayaan penutur terhadap mitos nasi menangis ketika kita makan 
tidak habis. mitos tersebut dikatakan oleh penutur sebagai sebuah keanehan karena mengapa hanya nasi yang menangis ketika kita makan tidak habis. dalam tuturan tersebut berisi ajakan oleh penutur untuk tidak percaya akan mitos tersebut jadi bisa dikatakan pada Tuturan (3) Video (1) merupakan tindak tutur ilokusi.

Tuturan (4) Video (1) : "tapi untungnya mitos nasi nangis itu gak beneran terjadi, kalo beneran terjadi gue takutnya terjadi kesenjangan sosial diantara para nasi yang kasihan itu nasi dirumah makan padang coba bayangin kalo ada orang makan disana terus gak habis, terus nasinya nangis siapa yang mau menghibur nasi disana tempe orek gak ada, dirumah makan pada gak ada makanan sebaik tempe orek adanya cuman rendang, kikil, emping makanan jahat semua berkolesterol itu" (Ridwan Remin)

pada Tuturan (4) Video (1) tuturan tersebut merupakan tindak tutur ilokusi karena penutur mengajak mitra tutur untuk membayangkan jika mitos itu benar-benar terjadi maka kemungkinan akan adanya kesenjangan sosial diantara para nasi. tuturan "coba bayangin" dari penutur merupakan suatu ajakan kepada mitra tutur untuk membayangkan apa yang akan terjadi sehingga tuturan itu bisa dikatakan sebagai tindak tutur ilokusi

Tuturan (1) Video (2): "Dari tadi banyak yang bilang Bedu gak terkenal masak sih, coba disini yang follow instagram nya Bedu boleh tepuk tangan kompas gak mau ganti orang nih, taruhannya rating loh." (Ridwan Remin)

Pada Tuturan (1) Video (2) menjelaskan tentang seorang bintang tamu dalam acara tersebut bernama Bedu yang merupakan seorang selebriti untuk dijadikan sebagai objek roasting namun saat itu sedikit sekali dari para penonton yang mengenal sosok seorang Bedu. hal ini menimbulkan reaksi dari penutur untuk menyarankan pihak penyelanggara acara untuk menggantinya sebagai bintang tamu dengan alesan taruhan rating acara televisi. Pada tuturan "kompas gak mau ganti orang" merupakan sebuah saran dari penutur sehingga kalimat tersebut bisa dikatakan sebagai tindak tutur ilokusi.

Tuturan (2) Video (2) : "Raisa dengan followers sebanyak itu maupun ngapain aja udah enak mau bikin meet and greet pasti rami yang dateng Raisa dengan followers sebanyak itu maupun ngapain aja udah enak mau bikin meet and greet pasti rami yang datang." (Ridwan Remin)

Tuturan (2) Video merupakan sebuah tindak tutur ilokusi karena penutur bermaksud untuk memberikan penawaran kepada selebriti untuk memiliki follower di sosial media yang banyak sehingga ketika melakukan kegiatan meet and greet bisa ramai penonton yang datang. hal tersebut merupakan tindak tutur ilokusi karena bermaksud untuk menawarkan pilihan kepada bintang tamu yang hadir. 
Tuturan (1) Video (4) : "tapi yah zaman sekarang yang namanya sehat itu susah, kalo sakit mah gampang kita tinggal keluar rumah hujanhujanan sakit, keluar rumah panas-panasan sakit bahkan waktu masih jadi pengangguran gue dirumah aja nggak ngapa-ngapain eh gue sakit, sakit hati di omongi tetangga." (Ridwan Remin)

Tuturan pada Tuturan (1) Video (4) merupakan sebuah tuturan yang berisi tentang cerita dari penutur pada zaman sekarang untuk hidup sehat itu susah sehingga penutur mengeluh dengan apa yang ia rasakan karena sulit sekali untuknya melakukan hidup sehat. tuturan tersebut dapat dikatakan tindak tutur ilokusi karena berisi keluhan dari penutur tentang sulitnya untuk hidup sehat.

Tindak tutur perlokusi adalah tindak tutur yang berkenaan dengan adanya ucapan orang orang lain sehubungan dengan sikap dan perilaku non linguistic dari orang lain (chaer \& agustina, 2004). Dengan demikian dapat disimpulkan bahwa tindak tutur perlokusi memiliki makna untuk mempengaruhi pendengarnya atau dimaksudkan untuk mempengaruhi mitra tutur. Berikut ini hasil analisis peneliti mengenai tindak tutur perlokusi oleh Ridwa Remin pada Stand Up Comedy Indonesia Season 7 Kompas TV edisi Juni 2017. analisis berdasarkan indikator yang sudah dijelaskan pada bab sebelumnya.

Tuturan (1) Video (1): "tapi untungnya mitos nasi nangis itu gak beneran terjadi kalo beneran terjadi gue takutnya terjadi kesenjangan sosial diantara para nasi yang kasihan itu nasi dirumah makan padang coba bayangin kalo ada orang makan disana terus gak habis, terus nasinya nangis siapa yang mau menghibur nasi disana tempe orek gak ada, dirumah makan pada gak ada makanan sebaik tempe orek adanya cuman rendang, kikil, emping makanan jahat semua berkolesterol itu." (Ridwan Remin)

Tuturan pada Tuturan (1) Video (1) memberikan efek kepada penutur untuk membayangkan sebuah kesejangan sosial yang akan terjadi pada para nasi apabila mitos nasi menangis benar-benar terjadi. efek dari tuturan tersebut secara tidak sengaja telah mempengaruhi penonton untuk membayangkan apa yang terjadi pada para nasi. dari tuturan tersebut bisa dikatakan bahwa tuturan itu adalah tindak tutur perlokusi karena memiliki efek secara tidak langsung terhadap mitra tutur untuk membayangkan.

Tuturan (1) Video (2): "Dari tadi banyak yang bilang Bedu gak terkenal masak sih, coba disini yang follow instagram nya Bedu boleh tepuk tangan kompas gak mau ganti orang nih, taruhannya rating loh." (Ridwan Remin)

Pada Tuturan (1) Video (2) penutur memberikan pengaruh terhadap mitra tutur untuk memberikan tepuk tangan apabila memfollow instagram Bedu. pengaruh ini secara sengaja dilakukan oleh mitra tutur atas permintaan dari penutur 
sehingga mampu untuk mengenali seberapa banyak orang yang mengenal sosok seorang Bedu. dari tuturan itu bisa dikatakan sebagai tindak tutur perlokusi karena secara sengaja adanya tindakan yang dilakukan oleh mitra tutur berupa tepuk tangan.

Tuturan (1) Video (3): "Gua percaya musik itu bisa jadi alat untuk mempersatukan umat coba disni yang gak suka sama musiknya Younglex boleh tepuk tangan, boleh lebih keras lagi rasakan betapa seorang Younglex bisa mempersatukan kita semua loh." (Ridwan Remin)

Tuturan pada kalimat Tuturan (1) Video (3) merupakan sebuah tindak tutur perlokusi karena adanya pengaruh terhadap mitra tutur yang dilakukan oleh penutur untuk mengetahui seberapa banyaknya penonton penonton yang tidak menyukai musiknya seorang rapper bernama younglex sebagai tanda bahwa musik dapat mempersatukan orang. pengaruh dilakukan secara sengaja oleh penutur untuk memperngaruhi mitra tutur jadi bisa dikatakan pada Tuturan(1) Video (3) ialah sebuah tindak tutur perlokusi.

Berdasarkan Hasil deskripsi analisis tindak tutur Ridwan Remin pada Stand Up Comedy Indonesia Season 7 Kompas TV edisi Juni 2017, dapat diketahui bahwa tindak tutur dalam penampilannya tersebut peneliti meneliti bagian dari tindak tutur lokusi, ilokusi, dan perlokusi. Tindak tutur merupakan gejala individual, Bersifat psikologis, dan ditentukan oleh kemampuan bahasa penutur dalam situasi tertentu. dengan demikian, tindak tutur adalah teori yang lebih cenderung meneliti makna kalimat bukan teori yang cenderung menganalisis struktur kalimat (Rani, 2006).

Tindak tutur adalah kegiatan sesorang menggunakan bahasa kepada mitra tutur dalam rangka mengomunikasikan sesuatu. Apa makna yang dikomunikasikan tidak hanya dapat dipahami berdasarkan penggunaan bahasa dalam bertutur tersebut tetapi juga ditentukan oleh aspek-aspek komunikasi secara komprehensif, termasuk aspek-aspek situasional komunikasi (Putrayasa, 2014). Pragmatik merupakan Suatu Proses dinamis yang melibatkan negosiasiasi antara pembaca dan pendengar antara konteks ujaran (penutur, latar, media, topic, dll) dan makna dalam interaksi (kohesi dan koherensi) (Wijana, 1996). dengan demikian, bahwa pragmatik bahwa Pragmatik adalah ilmu yang mempelajari tentang telaah makna yang tercakup dalam aspek-aspek informasi melalui bahasa dari penutur kepada pendengar. Segala jenis makna maksud dan tujuan dari penutur dikaji secara luas dengan menelaah makna makna dari setiap tuturan bahasa yang disampaikan oleh penutur sehingga penutur dapat merespon dan memberikan tindakan atas tuturan yang disampaikan oleh penutur.

Ditinjau juga dari penelitian sebelumnya karya Leni Sundari pada tahun 2016 dengan Judul "Analisis Tindak Tutur Lokusi, Ilokusi, dan Perlokusi Dalam Novel Seribu Kerinduan Karya Berlina P. Dewi". Penelitian sebelumnya memiliki keterkaitan dengan penelitian yang sekarang. pada penelitian sebelumnya membahas tentang tindak tutur lokusi, 
ilokusi dan perlokusii dalam novel seribu kerinduan karya Berlina $\mathrm{P}$. Dewi yang mengkaji tuturan pada kalimat dialog dalam novel tersebut sedangkan penilitian pada yang dilakukan penulis juga menganain tindak tutur lokusi, ilokusi dan perlokusi pada tuturan Ridwan Remin saat penampilannya dalam acara Stand Up Comedy Indonesia season 7 edisi Juni 2017.

Jadi, berdasarkan penelitian mengenai "Tindak Tutur Ridwan Remin Pada Stand Up Comedy Indonesia Season 7 Edisi Juni 2017" terdapat 5 video yang dianalisis yaitu video yang ditayangkan pada tanggal 02, 09, 16, 23 dan 30 Juni 2017 dengan tema berbeda. lalu diperoleh oleh peneliti sebanyak 20 tuturan oleh penutur yang termasuk tindak tutur lokusi dengan rincian 6 tuturan pada video pertama, 3 tuturan pada video kedua, 4 tuturan pada video ketiga, 3 tuturan pada video keempat dan 4 tuturan pada video kelima. tuturan terbebut dikatakan tindak tutur ilokusi karena pada tuturan tersebut berisi tentang informasi dan pernyataan dari penutur tanpa adanyan tindakan baik dari penutur maupun dari mitra tutur. kemudian diperoleh juga sebanyak 10 tuturan yang termasuk kedalam tindak tutur ilokusi dengan rincian 4 tuturan pada video pertama, 2 tuturan pada video kedua, 2 tuturan pada video keempat dan 2 tuturan pada video kelima. tuturan tersebut dikatakan tindak tutur ilokusi karena berisi informasi yang sekaligus memiliki maksud untuk mempengaruhi mitra tutur untuk melakukan sesuatu. lalu, terdapat sebanyak 3 tuturan yang merupakan tindak tutur perlokusi dengan rincian 1 tuturan pada video pertama, 1 tuturan pada video kedua dan 1 tuturan pada video ketiga. tuturan tersebut dikatakan tindak tutur perlokusi karena memiliki pengaruh kepada mitra tutur baik secara di sengaja maupun tidak disengaja.

Penggunaan tindak tutur ini akan berfungsi sebagai mana mestinya apabila seseorang akan menggunakannya saat bertutur kepada mitra tutur sehingga maksud dan tujuan dari penutur dapat tersampaikan dan ditangkap oleh mitra tutur sebagai lawam bicara dalam berkomunikasi serta menyampaikan sesuatu yang ingin disampaiakan.

\section{SIMPULAN}

Berdasarkan hasil penelitian dan pembahasan yang telah peneliti lakukan, maka disimpulkan sebagai berikut: (1) Terdapat tindak tutur lokusi, ilokusi dan perlokusi oleh tuturan Ridwan Remin Pada Stand Up Comedy Indonesia Season 7 Kompas TV edisi Juni 2017; (2) Dari data yang diperoleh dapat diketahui jenis tindak tutur lokusi berjumlah 20 kalimat dan merupakan tuturan yang paling sering digunakan; (3) Tindak tutur ilokusi pada data yang dianalisis berjumlah 10 kalimat; dan (4) Tindak Tutur perlokusi merupakan tindak tutur yang paling sedikit digunakan dengan jumlah 3 kalimat karena pada penampilan Stand Up Comedy Penonton merupakan Mitra tutur yang pasif.

\section{REFERENSI}

Aisyah, S. (2017). Public Speaking dan Kontribusinya Terhadap 
Kompetensi DAI. Jurnal Ilmu Dakwah, Vol 37, No.2.

Chaer, A, \& Agustina. (2004). Sosiolinguistik Perkenalan Awal. Jakarta: Rineka Cipta.

Cummings, L. (2007). Pragmatik Sebuah Perspektif Multidisipliner. Yogyakarta: Pustaka Pelajar.

Defina. (2018). Tindak Tutur Pada Anak-anak Saat Bermain Bola Dilapangan. Jurnal Kajian Bahasa.

Nadar, F. (2009). Pragmatik dan Penelitian Pragmatik. Yogyakarta: Graha Ilmu.

Nugroho, P. (2012). Potret Stand Up Comedy. Yogyakarta: Pustaka Baru.

Papana, R. (2012). Kitab Suci. Jakarta: Mediakita.

Pragiwaksono, P. (2012). Merdeka dalam Bercanda. Yogyakarta: Bentang Pustaka.

Putrayasa, I.B. (2014). Pragmatik. Yogyakarta: Graha Ilmu.

Rachman. (2015). Tindak Tutur Dalam Proses Belajar Mengajar Pada Taman Kanak-Kanak Dharma Wanita Kelurahan Wapunto Kecamatan Duruka Kabupaten Muna. Jurnal Humanika, No.15, Vol. 3.

Sukardi. (2010). Metedologi Penelitian Pendidikan Kompetensi dan Praktiknya. Jakarta: Bumi Aksara.

Tarigan, H.G. (2008). Berbicara. Bandung: Angkasa. (2008). Menyimak.

Bandung: Angkasa. (2009). Pengajaran

Pragmatik. Bandung: Angkasa.
Usman, H., \& Homo Setiady Akbar. (2001). Meteodologi Penelitian Sosial. Jakarta: Bumi Aksara.

Wahyuningsih, H., \& Zainal, R. (2017). Implikatur Percakapan dalam Stand Up Comedy 4. Jurnal Pendidikan Bahasa dan Sastra, Volume I.

Yanti, N.D. (2018). Penguasaan Materi Pembelajaran Keterampilan Berbahasa Indonesia Mahasiswa SI Program Studi Pendidikan Bahasa dan Sastra Indonesia FKIP Universitas Bengkulu. Jurnal Ilmiah Korpus, Volume 2(1).

Yule, G. (2014). Pragmatik. Yogyakarta: Pustaka Pelajar. 